\title{
AN INTEGRATIVE REVIEW OF THE POTENTIAL BARRIERS TO AND DRIVERS OF ADOPTING AND IMPLEMENTING SUSTAINABLE CONSTRUCTION IN SOUTH AFRICA
}

\author{
R.J. Marsh ${ }^{1 *}$, A.C. Brent ${ }^{1} \&$ I. H. de Kock ${ }^{1}$
}

\section{ARTICLE INFO}

\section{Article details \\ Presented at the $31^{\text {st }}$ annual conference of the Southern African Institute for Industrial Engineering (SAlIE), held virtually from 5-7 October 2020. \\ Available online \\ Contact details \\ * Corresponding author ralmar119@gmail.com \\ Author affiliations \\ 1 Department of Industrial Engineering, University of}

11 Nov 2020 Stellenbosch, South Africa

ORCID ${ }^{\circledR}$ identifiers

R.J. Marsh

https://orcid.org/0000-0001-9788-1032

A.C. Brent

https://orcid.org/0000-0003-3769-4512

I.H. de Kock

https: //orcid.org/0000-0003-4136-7418

DOI

http://dx.doi.org/10.7166/31-3-2417

\section{ABSTRACT}

While sustainable construction has gained increasing international attention, a limited number of studies address the issue of sustainable construction in South Africa. The adoption and implementation of sustainable solutions in the South African construction industry is also not apparent. The objective of this paper was to examine the most significant barriers to and drivers of the adoption and implementation of sustainable construction through an integrative review by systematically analysing the existing literature. This review identified six key themes in the literature: 1) socio-cultural barriers and drivers; 2) economic barriers and drivers; 3) stakeholder barriers and drivers; 4) political barriers and drivers; 5) technological barriers and drivers; and 6) the environmental benefits of adopting sustainable construction. An empirical investigation is ongoing to understand and analyse some of these barriers and drivers, with the aim of facilitating the transition to the adoption and successful implementation of sustainable construction in South Africa.

\section{OPSOMMING}

Alhoewel volhoubare konstruksie toenemende aandag internasionaal ontvang, is daar ' $n$ beperkte aantal studies wat dit binne die SuidAfrikaanse konteks aanspreek. Die aanneming en implementering van volhoubare oplossings in die Suid-Afrikaanse konstruksie industrie is nie duidelik nie. Die doel van hierdie artikel is om die mees noemenswaardige hindernisse tot en drywers van die aanneem en implementering van volhoubare konstruksie te ondersoek deur middel van 'n geïntegreerde, sistematiese literatuurstudie. Die studie het ses sleuteltemas identifiseer, naamlik 1) sosio-kulturele hindernisse en drywers; 2) ekonomiese hindernisse en drywers; 3) belanghebber verwante hindernisse en drywers; 4) politiese hindernisse en drywers; 5) tegnologiese hindernisse en drywers; en 6) omgewingsvoordele as gevolg van die aanneming van volhoubare konstruksie. 'n Empiriese ondersoek is van stapel gestuur om die hindernisse en aandrywers te verstaan en te ontleed. Die ondersoek hoop om die oorgang van aanneming tot suksesvolle implementering van volhoubare konstruksie in Suid-Afrika te fasiliteer.

\section{INTRODUCTION}

Over the past few decades, local and foreign governments have recognised that the construction industry, and specifically the built environment, is a key role player in the adoption and implementation of sustainable development. The construction industry, which includes the entire life cycle of a building from pre-feasibility to decommissioning and disposal, has a significant impact on the environment, economy, and society. From the literature it is evident that there are conflicting and varying interpretations and definitions of sustainable development and of how it should be applied in the construction industry. For developing countries such as South Africa, which faces issues with rapid urbanisation and infrastructure development, it is important to ensure that sustainable construction (SC) is adopted and effectively implemented at all phases of the building life cycle. This is critical in South Africa, where there is limited knowledge and understanding of sustainable construction practices. 
In order for the construction industry to contribute effectively to sustainable development, a more holistic definition of SC is required [1]. The debate about SC has been hindered by the perceived ambiguity and conflicting nature of the concept and of the terminologies associated with it [2]. Attempts to develop a generally accepted definition for SC have been unsuccessful thus far [3-5]. Du Plessis et al. [2] explain that the concept of SC extends beyond environmental sustainability: it embraces the contribution of economic and social sustainability, which highlights value creation by improving the quality of life of society. This view is supported by Kibert [6], who states that conventional design and construction would typically only focus on cost, performance objectives, and quality objectives. However, sustainable design and construction adds three additional criteria: minimising resource depletion, minimising environmental degradation, and creating a healthy built environment. Even with the lack of a general definition of SC, the key features of SC are identified in the literature, including these:

- $\quad$ SC considers the whole building project life cycle, which involves all stakeholders throughout all project phases.

- Environmental protection, sustainable growth of the economy, and quality of life of individuals and communities all need to work in harmony to achieve sustainability.

- $\quad$ SC encompasses both technological and non-technological solutions related to social and economic sustainability.

- $\quad$ The needs of present and future stakeholders must be addressed.

These key features of SC emphasise the significant impact that the construction industry has on determining the quality of life of individuals. In a study by Darko and Chan [7], SC is not seen as a priority in the construction industry. In developing countries that have a needs-driven environment, there is a concern that development focuses on quantitative delivery without considering issues of sustainability [8]. It is important, therefore, to raise awareness about SC, and educate stakeholders in the construction industry about the urgency of changing their approach to sustainable development. In order to develop appropriate strategies for a specific country to overcome the barriers to SC, it is necessary to understand which barriers affect the adoption of SC [7]. By identifying the barriers to SC, stakeholders in the construction industry can facilitate the development of sustainable solutions by understanding which drivers would lead to an increase in the adoption of SC.

The purpose of this review is to understand the behaviour of stakeholders in the construction industry by identifying the key potential barriers to and drivers of adopting and implementing SC practices. An integrative review approach has been adopted to identify the barriers to and drivers of SC, as detailed in the five-step integrative review process in Section 2 . Section 3 presents the results of the descriptive analysis of the literature, Section 4 provides the results from the content analysis of the literature review, and Section 5 discusses the conclusions drawn from the review.

\section{LITERATURE REVIEW METHODOLOGY}

Integrative reviews provide a more comprehensive understanding of a particular phenomenon, as they allow the inclusion of both experimental and non-experimental research to understand a phenomenon of concern more holistically [9]. The concept of SC has not been extensively explored in the literature, and therefore the integrative review aids the understanding of this concept and what the potential barriers and drivers are in the adoption of SC. Integrative reviews also allow deductions to be made transparently, as all relevant, sound research with diverse methodologies is included [9]. This aids the purpose of this review by generating an overall view of the evidence available in the literature for SC. The five-step integrative review process used in this review is detailed in the sub-sections below.

\subsection{Step 1: Problem identification}

The construction industry in South Africa is a large contributor to the development and growth of the economy. The industry also has a significant impact on the sustainability of the built environment, considering that it is a vehicle used to address challenges such as the lack of infrastructure, insufficient housing, and rapid urbanisation. These challenges are specifically dominant in developing countries such as South Africa. The preliminary investigation suggests that, without the adoption of SC practices in the industry, these challenges will continue significantly to impact the sustainability of resources and the environment, and compromise the needs of both present and future generations. However, in South Africa there is limited research into the barriers and challenges facing the construction industry; and that hinders the successful adoption and implementation of SC. To overcome the barriers, we have to identify the factors and drivers that would promote the successful adoption of SC. Therefore, the purpose of this 
integrative review is to identify the key barriers and drivers faced by other countries, and to use this to develop intervention strategies to overcome these barriers and promote the drivers of SC in South Africa.

\subsection{Step 2: Literature search}

The integrative review specifically focuses on the barriers to and drivers of the successful adoption and implementation of SC. An online search was conducted using Scopus as the main database, with additional searches conducted in Google Scholar and Science Direct. As highlighted in the literature, various terms for SC are used interchangeably. This review therefore adopted keywords and synonyms, as shown in Table 1, as well as specific inclusion criteria to identify and select articles.

Table 1: Selection criteria for articles

\begin{tabular}{|c|c|c|}
\hline No & \multicolumn{2}{|c|}{ Inclusion criteria } \\
\hline \multirow{2}{*}{1} & \multirow{2}{*}{ Type } & Journal articles \\
\hline & & Conference proceedings \\
\hline 2 & Year & $2009-$ present \\
\hline \multirow{4}{*}{3} & \multirow{4}{*}{ Keywords } & $\begin{array}{l}\text { "sustainable construction" OR "sustainable building" OR “construction sustainability" OR "green } \\
\text { building" OR "sustainable development" }\end{array}$ \\
\hline & & $\begin{array}{l}\text { "construction industry" OR "building construction" OR "construction management" OR } \\
\text { "engineering management" OR "construction and engineering management" }\end{array}$ \\
\hline & & "barriers” OR “obstacles” OR “challenges” OR “impediments” \\
\hline & & "drivers" OR "promoting” OR “motivating factors" \\
\hline \multirow{6}{*}{4} & \multirow{6}{*}{$\begin{array}{l}\text { Subject } \\
\text { area }\end{array}$} & Engineering \\
\hline & & Environment \\
\hline & & Society \\
\hline & & Business \\
\hline & & Decision-making \\
\hline & & Earth \\
\hline
\end{tabular}

The search strategy process for both barriers and drivers are shown in Figure 1 . The initial literature search for the barriers and drivers rendered 650 and 249 articles respectively. From the literature search, which initially rendered 899 articles in total, only 37 articles met the inclusion criteria and were relevant to the current study. The relevance to the study was based on the applicability and quality of the articles. The applicability was guided by the inclusion criteria, and the quality appraisal was guided by whether the abstract, introduction, and conclusion indicated that the article was relevant to the study, and whether or not the research design approach and methodologies adopted in the articles lent themselves to being applicable to South Africa. The initial search rendered a large number of articles with at least one of the keywords in the title, abstract, or keywords of the articles that met the initial search requirements. However, further analysis using a content review was done to ensure that the articles discussed, assessed, and potentially examined the barriers and (or) drivers to the adoption and implementation of SC. It is important to note that this study provides insights based on the selected articles and does not review all of the articles potentially published in other literature databases, books, dissertations, and other media. This literature review therefore only analyses articles obtained using the above-mentioned selection criteria.

\subsection{Step 3: Data evaluation}

According to Whittemore and Knafl [9], extracting the methodological features of primary sources or selected literature in meta-analysis, systematic, and integrative reviews is recommended to assess the overall quality. Integrative reviews potentially include empirical sources with similar research methods, empirical sources with various research methods, or sources that are empirical and theoretical [9]. For each of these scenarios, a different method of assessing the quality can be adopted. Sources with similar research methods can use exclusion and inclusion criteria to calculate quality scores, and then incorporate these scores into the design. On the other hand, sources with diverse research methods may only reasonably be evaluated for quality if certain outliers might infer that the methodological quality of the source is a feasible reason for the discrepancy in the findings. For studies that include empirical and theoretical sources, evaluating the quality, similar to that of historical research, may be appropriate [9]. Whittemore and Knafl [9] argue that each research method has different criteria that exemplify quality, and therefore the process of evaluating quality would be more conducive to reviews with similar or identical research methods. The sample of the literature selected for this review included empirical research with a variety of research methods. No article that was reviewed had a significant outlier that could be linked to the methodological approach, and therefore all articles were deemed acceptable. 


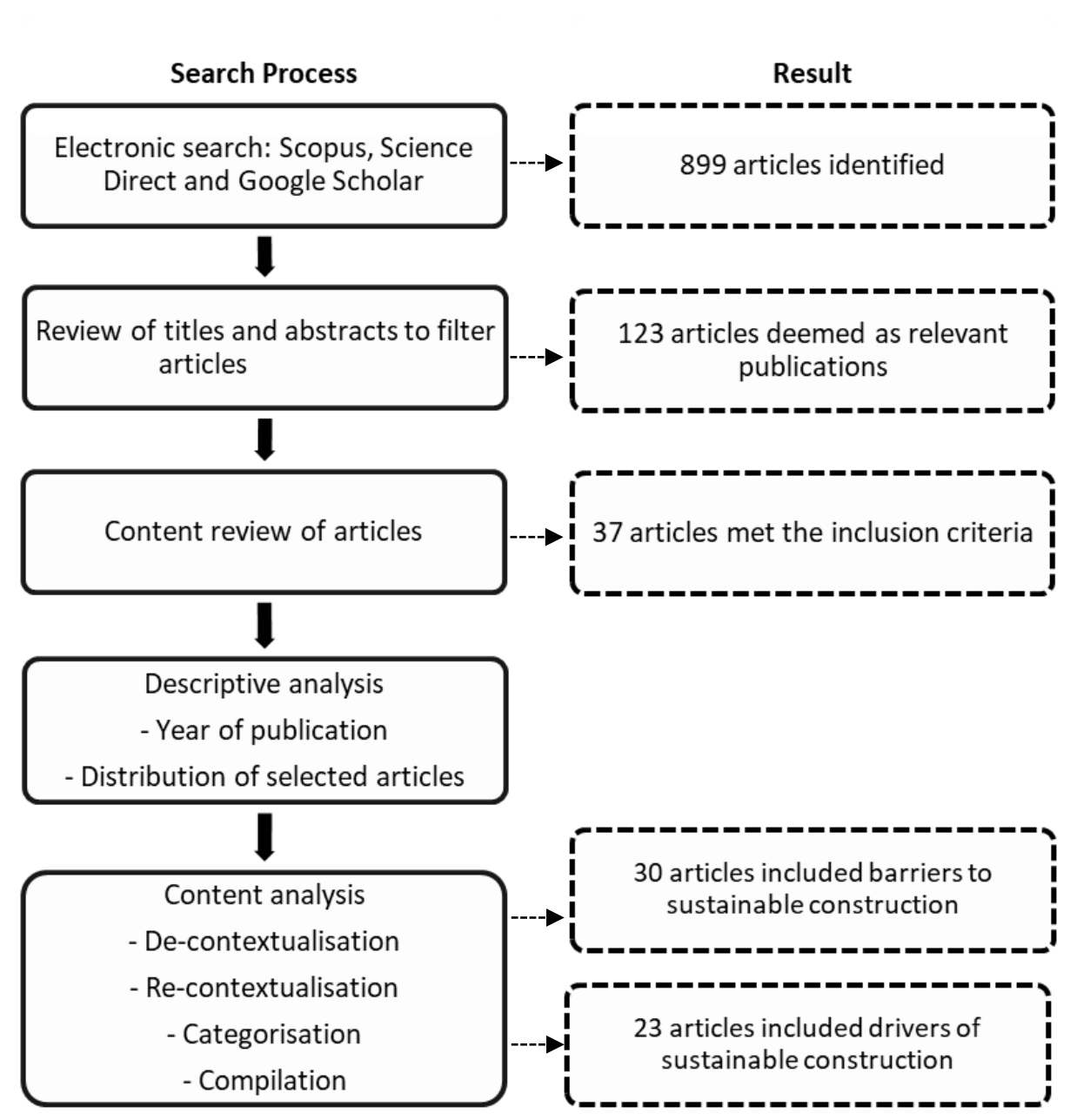

Figure 1: Search strategy process to identify barriers and drivers

\subsection{Step 4: Data analysis}

To analyse the data in a research review, the data needs to be categorised, ordered, coded, and summarised. According to Whittemore and Knafl [9], an unbiased and thorough interpretation of the data and synthesis of the evidence is the aim of the data analysis stage in an integrative review. A method of constant comparison is used in this review to convert the data, which has been extracted into categories that enable the identification of trends, themes, distinctions, and relationships. Initially, the extracted data is compared item by item so that similar data is categorised and coded. The coded categories are then compared, furthering the analysis and synthesis of the data. Whittemore and Knafl [9] state that this approach to data analysis in an integrative review is appropriate with the use of data from sources with various research methods. After identifying the relevant articles, a descriptive analysis was conducted to characterise the selected articles using frequency and percentage methods. The factors used in the descriptive analysis provide an overview of the year of publication, the publication type, the country or region of publication, and the research approach and method adopted in the study.

A content analysis was conducted following the descriptive analysis inductively to assess, identify, and contextualise the categories of barriers and drivers that hinder or promote the adoption and implementation of SC. Content analysis is a technique that uses a structured and systematic coding and categorisation approach to examine and identify trends and patterns among a string of words, and compresses them into fewer content categories [10-11]. Although preparation, organisation, and reporting are the three major components of the content analysis process, there are no systematic rules for data analysis, and the goal of all content analysis is to condense many words in the text into much smaller content categories [12]. To conduct the content analysis, a four-stage approach proposed by Bengtsson [13] was used, as follows: 


\subsubsection{Stage 1: De-contextualisation}

This stage involved making sense of the data and selecting a unit of analysis. The unit of analysis for this content analysis is themes as opposed to physical linguistic units (e.g., words, sentences, or paragraphs). Themes represent an expression or idea using a single word, phrase, sentence, or even an entire document [13]. A code can therefore be assigned to a theme that represents any size of text as long as it is representative of a single theme [14]. The coding process in this study used the themes of barriers to and drivers of SC as the units of analysis. An initial standardised list of coding groups was established to decontextualise the text in the articles (as shown in Table 2), and to identify the articles based on the descriptive analysis. All the information in the selected articles was manually extracted and recorded in a Microsoft Excel spreadsheet, which refers to the code list.

Table 2: Initial article code list

\begin{tabular}{|l|l|}
\hline Code & Code list \\
\hline Year & Year of publication of article \\
\hline Author(s) & List of authors \\
\hline Article title & Title of article \\
\hline Journal or conference & Journals or conferences where article has been published \\
\hline Country & Country or region where data was collected \\
\hline Research approach & Research approach used in the study \\
\hline Research method & Research methods used to collect data \\
\hline Barriers & Barriers identified that hinder sustainable construction adoption and implementation \\
\hline Drivers & Drivers identified that promote sustainable construction adoption and implementation \\
\hline
\end{tabular}

\subsubsection{Stage 2: Re-contextualisation}

Stage 2 refers to the process of open coding by condensing the various descriptions of the unit of analysis under the two major themes - the barriers to and drivers of SC. The first step of re-contextualisation involves labelling the extracted meanings with explicit codes or sub-themes under the major themes, based on their similarity. For example, statements that indicate that increased cost, time, and risk are associated with the adoption of SC were coded as 'economic barriers' in the open coding process. The codes of subthemes can easily be collected throughout this stage, and so freely generate categories [12].

\subsubsection{Stage 3 and 4: Categorisation and compilation}

Categorising during Stage 3 requires sorting the sub-themes into categories, followed by a compilation process. During the categorising process, similar or dissimilar sub-themes are collapsed into broader subthemes that provide the grouping lists of sub-themes in Stage 2. Each sub-theme was then named according to the content-specific words in that category. The data was then recorded in a new Excel spreadsheet to track the number of studies for each sub-theme.

\subsection{Step 5: Interpretation of results}

The interpretation and findings from the data analysis of the integrative review are presented in Sections 3 and 4.

\section{DESCRIPTIVE ANALYSIS RESULTS}

After evaluating the articles in the literature, 37 articles met the inclusion criteria and were selected to be classified and coded. Journal articles accounted for 89 per cent ( 33 articles) of the selected publications, and conference papers accounted for 11 per cent (four articles). Figure 2 indicates the annual number of selected articles that have been published, with a trend of fluctuating growth since 2009, varying between one and six articles published per annum. Most of the articles were published between 2013 and 2019, which indicates an increased interest in this research field. The maximum number of articles published annually (six) were published in each of the years 2014, 2015, and 2019.

Considering the possible variation in the social, economic, political, and cultural contexts, the countries or regions of origin of the articles were identified, as shown in Figure 3. The 37 articles covered a total of 19 countries and regions, including both developed and developing countries, with the most articles published in Australia (five), Ghana (four), Malaysia (four), China (three), the United States (three), and the United Kingdom (three). In the context of this review, most of the articles were from developing countries (21); the other 16 were published in developed countries. 


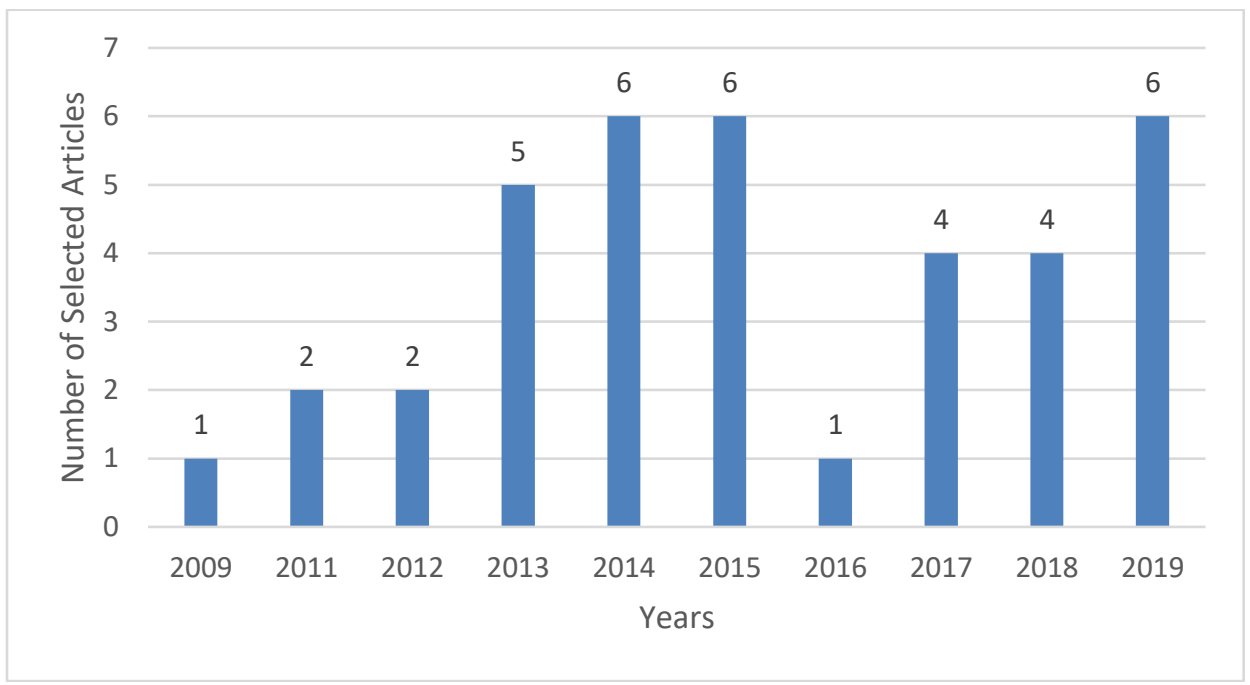

Figure 2: Number of selected articles

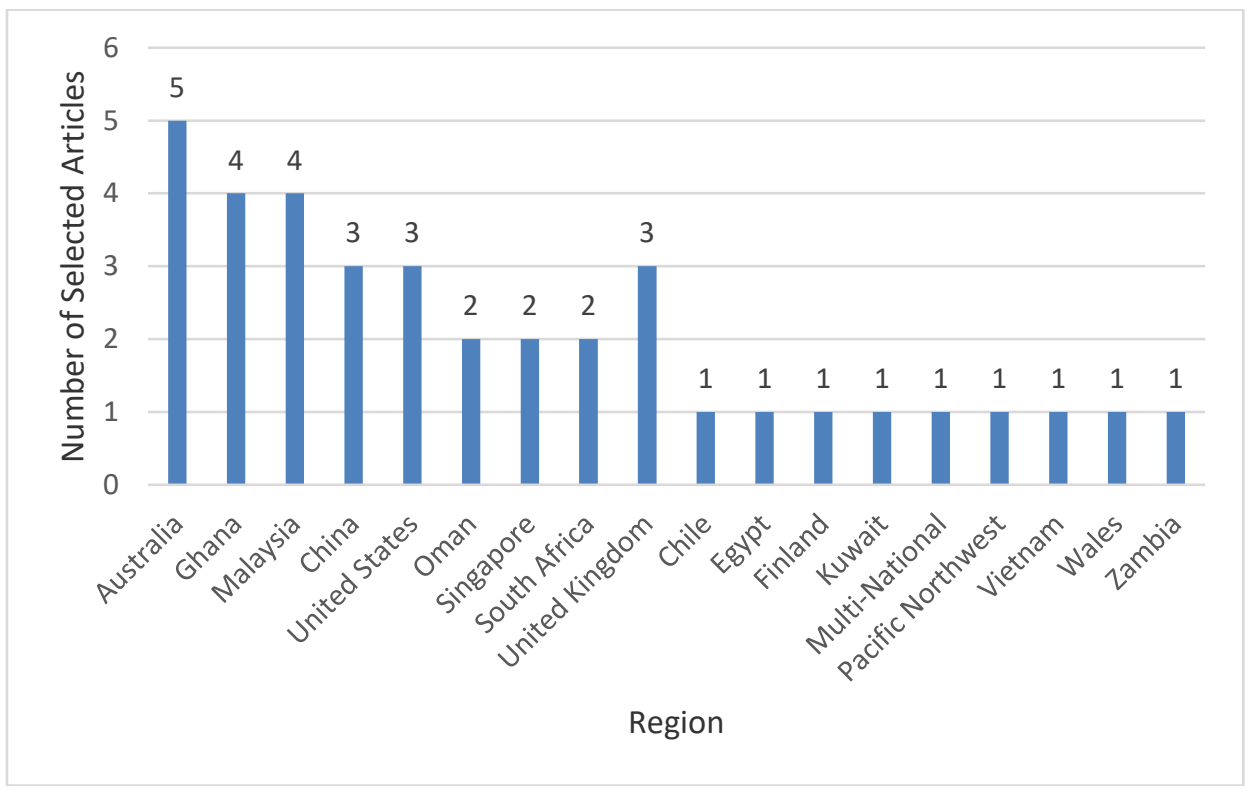

Figure 3: Distribution of selected articles by country or region

\subsection{Research approach and methods}

The analysis of the articles indicated that all the studies were empirical and included qualitative, quantitative, and mixed method approaches, as shown in Figure 4. Most articles (22) adopted a quantitative approach to the research study, while mixed methods and qualitative studies only accounted for nine and six articles respectively, of the selected 37 articles. There is therefore an opportunity for more conceptual studies to be adopted using both a theoretical approach and a qualitative research approach. Similarly, there is the potential to increase the adoption of mixed method approaches, as that would lead to greater data validation and triangulation in research studies. Figure 5 shows that questionnaires, as a research method, accounted for most of the articles, indicating that quantitative studies adopted questionnaires as a primary research method, while qualitative studies used focus groups, workshops, case studies, and interviews. Mixed method studies predominantly used a combination of survey questionnaires with interviews. 


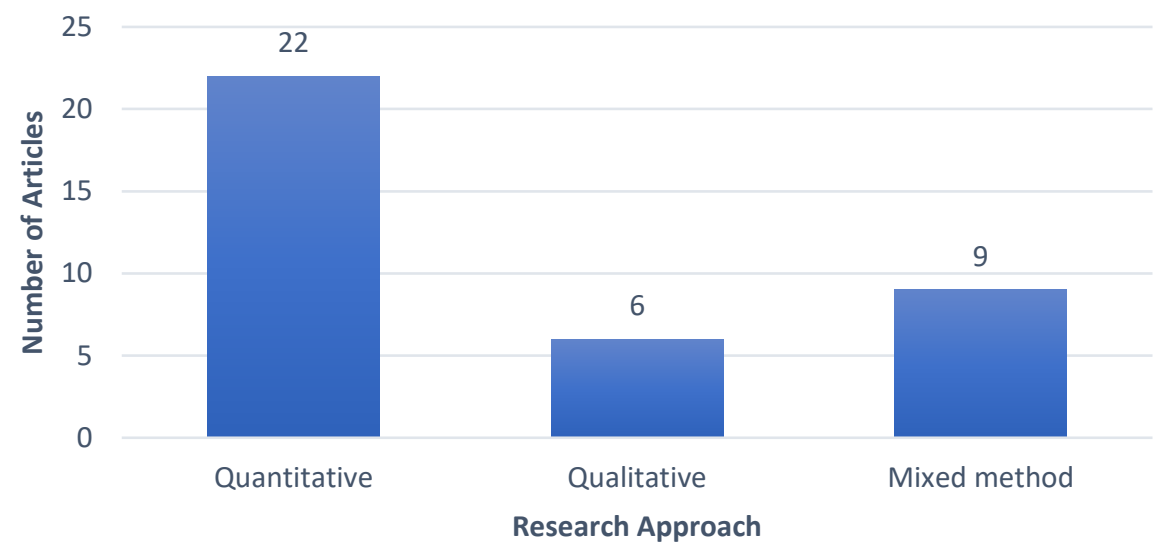

Figure 4: Research approach of articles

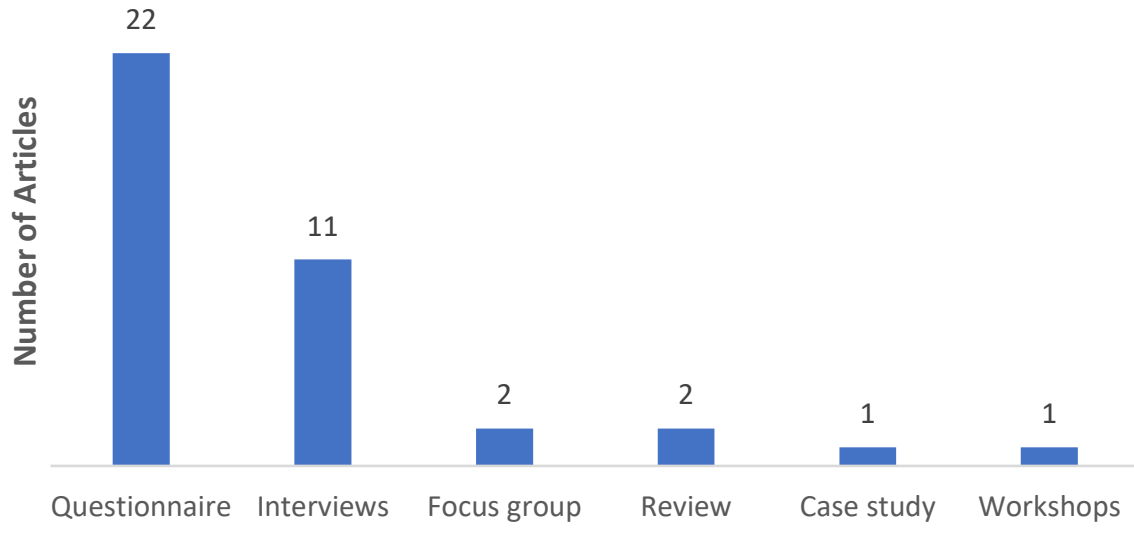

Research Methods

Figure 5: Research methods adopted in articles

\section{CONTENT ANALYSIS RESULTS}

\subsection{Barriers to sustainable construction}

To develop a more meaningful interpretation of the data, the emerging themes of the barriers in the literature were grouped based on the existing literature, and are summarised under five key themes:

- Socio-cultural barriers: barriers related to the aspects of social norms and cultural values in the context of the construction industry that inhibit the adoption and implementation of SC.

- $\quad$ Economic barriers: barriers focused on the financial implications that are related to aspects of the construction industry as a market, including the cost, time, and risk associated with adopting SC practices.

- Stakeholder barriers: barriers related to leadership and management in the construction industry, mentoring, methods of application, and demonstration of SC and strategies relating to the promotion of SC.

- Political barriers: barriers related to government, regulations, laws, policies, incentives, initiatives, and performance measurement tools to identify and incentivise the application of SC.

- Technological barriers: barriers related to the products, materials, and technological specifications required to implement SC successfully.

After classifying the articles according to the key theme categories, they were reviewed in detail to identify the sub-theme categories and the frequency of citations, as shown in Table 3 . The most frequently cited 
barriers across all articles include: a lack of knowledge of SC (17); resistance to changing traditional construction processes (17); a lack of building codes and regulations (17); a lack of government support and incentives (17); and limited availability of green product suppliers, materials, and technologies (17).

20 articles out of the 30 that only focused on the barriers to SC adoption ranked the barriers in order of the most important perceived barriers. Economic barriers were found to be ranked first by most authors. These barriers are mainly cost-related constraints, such as the initial cost of SC [15], [22], [34], the lack of credit resources to cover initial costs [43], the additional costs caused by SC [18], [23], [25], [35] and the real up-front cost compared with the return on investment [40]. Authors ranked socio-cultural barriers as the second most important barrier. The identified socio-cultural barriers highlighted the lack of information about how SC affects the operational cost of a project [42], the perceived increased costs of SC practices [35], [40], a lack of awareness, knowledge, and understanding of SC and its benefits [25], [27], and a lack of client demand [15]. Economic barriers ranked third, emphasised the construction industry maintaining its current practices [34]; which relates to the industry prioritising economic needs above social and environmental needs [17]. Furthermore, cost-related barriers related to the poor performance of the economy [35], [40] mean that an increased risk is associated with adopting and investing in sustainable alternatives in the construction industry [21], [31]. Barriers related to stakeholders and their perspectives were ranked fourth [15], [18], [20], [21], [31], [35], highlighting the general lack of professional skills and expertise [20], [21] in the construction industry that would adequately provide a strong business case for SC [15]. Stakeholders are more likely to pursue traditional procurement methods [31] to avoid the additional responsibilities required to implement SC practices, and to manage the conflicting and competing targets of their organisations' business aims [35]. The barriers ranked as being the fifth most important factor to consider when adopting and implementing SC illustrate the important role that government has to play. Häkkinen and Belloni [42], Darko et al. [29], and Djokoto et al. [37] argue that, without government support and incentives, industry stakeholders are unlikely to adopt SC practices. A lack of building codes and regulation [43], the bureaucracy of governments [17], and a lack of sustainable performance tools [18] further hinder the adoption and successful implementation of SC.

Table 3: Barriers to sustainable construction

\begin{tabular}{|c|c|c|c|}
\hline Themes & Sub-theme categories & References & Citations \\
\hline \multirow{6}{*}{$\begin{array}{l}\text { Socio-cultural } \\
\text { barriers }\end{array}$} & Lack of knowledge of SC & {$[15],[16],[19],[21],[24-29],[30-38]$} & 17 \\
\hline & Lack of understanding of SC & $\begin{array}{l}{[16],[17],[19],[21],[24-26],[30],[34],} \\
{[39]}\end{array}$ & 10 \\
\hline & Lack of awareness of SC & $\begin{array}{l}{[17],[19],[21],[22],[24-26],[30],[32-} \\
34],[36],[37],[40-42]\end{array}$ & 16 \\
\hline & Lack of training and education in SC & $\begin{array}{l}\text { [17], [19], [21], [22], [24], [26], [31], } \\
{[35],[38],[42],[43]}\end{array}$ & 11 \\
\hline & Perceived increased cost of SC & $\begin{array}{l}\text { [15], [16], [17], [19], [24], [29], [31-34], } \\
{[39],[42],[43]}\end{array}$ & 13 \\
\hline & $\begin{array}{l}\text { Lack of interest in green initiatives and } \\
\text { SC }\end{array}$ & {$[16],[19],[21],[24],[25],[31-33],[40]$} & 9 \\
\hline \multirow[t]{5}{*}{$\begin{array}{l}\text { Economic } \\
\text { barriers }\end{array}$} & $\begin{array}{l}\text { Long payback periods for green } \\
\text { technologies }\end{array}$ & {$[17],[19-21],[23-28],[32],[41-45]$} & 16 \\
\hline & $\begin{array}{l}\text { Increased cost of sustainable materials } \\
\text { and products increases the capital cost }\end{array}$ & {$[19],[22-25],[29],[33],[37],[39],[45]$} & 10 \\
\hline & $\begin{array}{l}\text { Implementing SC practices is time- } \\
\text { consuming, which causes project delays }\end{array}$ & $\begin{array}{l}\text { [18], [19], [22], [24], [26], [27], [30], } \\
{[33],[34],[44]}\end{array}$ & 10 \\
\hline & $\begin{array}{l}\text { Risk of investment with new sustainable } \\
\text { materials and methods }\end{array}$ & {$[19],[21],[22-26],[31-33],[41],[45]$} & 12 \\
\hline & $\begin{array}{l}\text { Lack of client demand for SC projects } \\
\text { from clients }\end{array}$ & $\begin{array}{l}{[19],[21],[22-25],[27],[29],[32],[34],} \\
{[40],[43],[45]}\end{array}$ & 13 \\
\hline \multirow[t]{3}{*}{$\begin{array}{l}\text { Stakeholder } \\
\text { barriers }\end{array}$} & $\begin{array}{l}\text { Lack of professional knowledge and } \\
\text { expertise }\end{array}$ & $\begin{array}{l}\text { [19], [21], [22-26], [28], [31], [32], [33], } \\
{[35],[41-42]}\end{array}$ & 14 \\
\hline & $\begin{array}{l}\text { Resistance to changing traditional } \\
\text { construction processes }\end{array}$ & $\begin{array}{l}{[16],[17],[32],[38],[40-43],[45],[19],} \\
{[21],[22],[24-26],[28],[31]}\end{array}$ & 17 \\
\hline & $\begin{array}{l}\text { Lack of integrated work environment } \\
\text { and communication among all } \\
\text { stakeholders }\end{array}$ & {$[15-17],[22],[26],[35],[36],[45]$} & 8 \\
\hline \multirow[t]{3}{*}{$\begin{array}{l}\text { Political } \\
\text { barriers }\end{array}$} & Lack of building codes and regulation & $\begin{array}{l}\text { [15], [16], [33], [36], [38-40], [42], [43], } \\
{[18],[21-25],[30],[31]}\end{array}$ & 17 \\
\hline & $\begin{array}{l}\text { Lack of monitoring and enforcement } \\
\text { through building codes and regulation }\end{array}$ & $\begin{array}{l}\text { [16], [18], [40], [42], [19], [28-31], [33], } \\
\text { [37], [38] }\end{array}$ & 12 \\
\hline & $\begin{array}{l}\text { Lack of government support and } \\
\text { incentives }\end{array}$ & $\begin{array}{l}{[16],[17],[30],[32],[37],[38],[42],} \\
{[43],[18],[20-24],[26],[29]}\end{array}$ & 17 \\
\hline
\end{tabular}




\begin{tabular}{|l|l|l|l|}
\hline Themes & Sub-theme categories & References & Citations \\
\hline \multirow{3}{*}{$\begin{array}{l}\text { Technological } \\
\text { barriers }\end{array}$} & $\begin{array}{l}\text { Lack of adequate green technological } \\
\text { specifications }\end{array}$ & {$[18],[21],[22],[24],[26],[27],[32]$,} & 9 \\
\cline { 2 - 4 } & Limited availability of green product & {$[38],[43]$} & $16],[18],[32-34],[38-40],[44],[19]$, \\
& suppliers, materials, and technologies & {$[21-23],[25],[27],[30],[31]$} & 17 \\
\cline { 2 - 4 } & $\begin{array}{l}\text { Lack of databases and information for } \\
\text { green technologies }\end{array}$ & $\begin{array}{l}{[18],[19],[43],[22],[26],[27],[29],} \\
{[30],[37],[38],[42]}\end{array}$ & 11 \\
\hline
\end{tabular}

\subsection{Drivers of sustainable construction}

Table 4 illustrates the six main theme categories of drivers, sub-theme categories, and the frequency of citations from various authors in the literature. The most frequently cited drivers were governments' support and encouragement to adopt SC through financial and market-based incentives (16), increasing the awareness of SC among stakeholders (11), developing mandatory SC building and planning policies and regulations (11), developing rating systems and standards with sustainable design guidelines and construction standards (9), improving product and material innovation and providing certification (8), and increasing education about SC among stakeholders (8).

Twelve articles out of the 23 that only focused on drivers of SC ranked the drivers in order of most critical to increasing the adoption and implementation of SC. Drivers related to stakeholders and their perceptions was ranked first by most authors. These drivers highlight the importance of construction industry stakeholders setting a standard for future design and construction [52] through innovation [31] and adopting sustainable alternatives to traditional construction processes. The success of SC is also dependent on the participation and collaboration of all industry stakeholders [47], which can be enhanced through linking research about SC with those who need to implement it (i.e., construction industry stakeholders) [46]. Political drivers were ranked second to fifth by most authors, which emphasises the importance of governments in driving the agenda of SC adoption and implementation through mandatory regulations and policies [17], [46], [48], green design guidelines and construction standards [20], [31], [47], financial and market-based incentives for SC adopters [28], [48], tax relief for developers and contractors for the use of sustainable building products, systems, and technologies, and providing subsidies for research and development of sustainable building products, systems, and technologies [28].

Table 4: Drivers of sustainable construction

\begin{tabular}{|c|c|c|c|}
\hline Themes & Sub-theme categories & References & Citations \\
\hline \multirow[t]{6}{*}{ Socio-cultural drivers } & $\begin{array}{l}\text { Increase awareness of SC among construction industry } \\
\text { stakeholders }\end{array}$ & $\begin{array}{l}{[15],[18],[21],} \\
{[26],[32],[34],} \\
{[36],[38],[42]} \\
{[45-46]}\end{array}$ & 11 \\
\hline & $\begin{array}{l}\text { Increase education programmes about SC for } \\
\text { construction industry stakeholders }\end{array}$ & $\begin{array}{l}\text { [18], [21], [29], } \\
{[31],[34],[44],} \\
{[46-47]}\end{array}$ & 8 \\
\hline & $\begin{array}{l}\text { SC on building projects improves indoor environmental } \\
\text { quality, and enhances occupants' health, comfort, and } \\
\text { well-being }\end{array}$ & $\begin{array}{l}{[19],[32],[34],} \\
{[47-48]}\end{array}$ & 5 \\
\hline & Increased client/stakeholder demand & $\begin{array}{l}{[15],[26],[36],} \\
{[45-46],[49],[50]}\end{array}$ & 7 \\
\hline & $\begin{array}{l}\text { Adopting and implementing SC reduces the whole } \\
\text { lifecycle cost of a building }\end{array}$ & $\begin{array}{l}\text { [27], [34], [36], } \\
{[48],[50]}\end{array}$ & 5 \\
\hline & High return on the investment if SC is implemented & $\begin{array}{l}{[15],[31],[42]} \\
{[48-49],[51]}\end{array}$ & 6 \\
\hline \multirow[t]{2}{*}{$\begin{array}{l}\text { Environmental } \\
\text { drivers }\end{array}$} & SC promotes protection of the environment & $\begin{array}{l}{[19],[32],[36]} \\
{[46],[48-49]}\end{array}$ & 6 \\
\hline & SC promotes waste reduction & $\begin{array}{l}{[19],[34],[47-} \\
48],[50]\end{array}$ & 5 \\
\hline \multirow[t]{3}{*}{ Stakeholder drivers } & $\begin{array}{l}\text { SC could build a good corporate image and reputation } \\
\text { in the industry }\end{array}$ & $\begin{array}{l}\text { [15], [19], [36], } \\
{[45],[47-48],[51]}\end{array}$ & 7 \\
\hline & $\begin{array}{l}\text { SC provides an integrated building design approach } \\
\text { with multiple project stakeholders }\end{array}$ & $\begin{array}{l}{[23],[34],[36],} \\
{[44-46]}\end{array}$ & 6 \\
\hline & $\begin{array}{l}\text { Organisations should provide dedicated resources, and } \\
\text { sustainability expertise for facilitating green } \\
\text { procurement and decision-making }\end{array}$ & $\begin{array}{l}{[18],[20],[31],} \\
{[46],[50-51]}\end{array}$ & 6 \\
\hline Political drivers & $\begin{array}{l}\text { Government should encourage and support SC through } \\
\text { financial and other market-based incentives }\end{array}$ & $\begin{array}{l}{[15],[18],[20-} \\
21],[23],[29], \\
{[31-32],[34]} \\
{[36],[38],[42],}\end{array}$ & 16 \\
\hline
\end{tabular}




\begin{tabular}{|c|c|c|c|}
\hline \multirow[t]{7}{*}{ Themes } & \multirow{3}{*}{$\begin{array}{l}\text { Sub-theme categories } \\
\text { Updated land use regulations and urban planning } \\
\text { policies }\end{array}$} & \multirow{2}{*}{$\begin{array}{l}\text { References } \\
\text { [44-45], [47], } \\
\text { [51], }\end{array}$} & \multirow[t]{2}{*}{ Citation } \\
\hline & & & \\
\hline & & $\begin{array}{l}\text { [15], [29], [34], } \\
{[38],[42],[44-45]}\end{array}$ & 7 \\
\hline & $\begin{array}{l}\text { Performance-based measurements such as green } \\
\text { building rating systems, and sustainable design } \\
\text { guidelines and construction standards }\end{array}$ & $\begin{array}{l}{[18],[21],[29],} \\
{[31],[34],[38],} \\
{[44],[49-50]}\end{array}$ & 9 \\
\hline & $\begin{array}{l}\text { Mandatory SC building and planning policies, } \\
\text { regulations }\end{array}$ & $\begin{array}{l}\text { [15], [18], [21], } \\
{[26],[31-32],} \\
{[38],[42],[45],} \\
{[50-51]}\end{array}$ & 11 \\
\hline & $\begin{array}{l}\text { Better enforcement of green building policies after } \\
\text { they have been developed }\end{array}$ & $\begin{array}{l}{[18],[21],[45-} \\
46],[50]\end{array}$ & 5 \\
\hline & $\begin{array}{l}\text { Tax relief should be available to developers and } \\
\text { contractors for using sustainable building products, } \\
\text { systems, and technologies }\end{array}$ & $\begin{array}{l}\text { [15], [17], [28], } \\
{[38],[42]}\end{array}$ & 5 \\
\hline Technological drivers & $\begin{array}{l}\text { Product and material innovation for SC should be } \\
\text { readily available }\end{array}$ & $\begin{array}{l}{[23],[31-32],} \\
{[34],[45],[46],} \\
{[50-51]}\end{array}$ & 8 \\
\hline
\end{tabular}

\section{CONCLUSION}

This integrative review provides an overview of the scope of the barriers to and drivers of SC in the current literature. By quantifying which barriers and drivers are most prominent in the literature that occurred predominantly in developing countries, it identifies which barriers need to be targeted to increase the adoption and implementation of SC, and which drivers need to be focused on to enable the implementation of $\mathrm{SC}$ in the South African context further.

Based on the integrative review of 37 articles, the descriptive analysis shows that there has been an increasing interest in SC among researchers, with studies focused on both developing and developed countries. A quantitative research approach was the most common strategy of inquiry using survey questionnaires, with only a few studies adopting qualitative and mixed methods approaches. This reveals that there is an opportunity to enhance the research in this field by adopting qualitative and mixed methods to improve the validation and triangulation of the data.

The content analysis provides insight into the key themes of the barriers to and drivers of SC. Six key themes, identified in the literature, group the potential barriers to and drivers of the implementation of SC as: 1) socio-cultural barriers and drivers; 2) economic barriers and drivers; 3) stakeholder barriers and drivers; 4) political barriers and drivers; 5) technological barriers and drivers; and 6) environmental drivers. Twenty-two barriers to and 45 drivers of SC were identified from the review of the literature.

The top five barriers to adopting and implementing SC are the lack of knowledge of SC, resistance to changing traditional construction processes, a lack of building codes and regulations, a lack of government support and incentives, and limited availability of green product suppliers, materials, and technologies. The top six identified drivers to enable the adoption and implementation of SC are: governments' support and encouragement to adopt SC through financial and market-based incentives; increasing the awareness of SC among stakeholders; developing mandatory SC building and planning policies and regulations; developing rating systems and standards with sustainable design guidelines and construction standards; improving product and material innovation and providing certification; and increasing the education about SC among stakeholders.

The barriers to and drivers of SC highlighted in this review have a general applicability to all stakeholders in the construction industry. A future review study could compare the findings on the barriers to and drivers of SC from the perspectives of the same or different groups of stakeholders. This paper provides a platform to conduct an empirical study in the South African context to explore and analyse the barriers to and drivers of SC that would facilitate the successful implementation of SC.

\section{REFERENCES}

[1] Pearce, D. 2003. The social and economic value of construction: The construction industry's contribution to sustainable development. www.ncrisp.org.uk.

[2] Du Plessis, C. 2002. Agenda 21 for sustainable construction in developing countries. Discussion document. Report No. Bou/E. 
[3] Hill, R.C. \& Bowen, P.A. 1997. Sustainable construction: Principles and a framework for attainment. Construction Management and Economics, 15(3), pp. 223-239.

[4] Du Plessis, C. 2007. A strategic framework for sustainable construction in developing countries. Construction Management and Economics, 25(1), pp. 67-76.

[5] Ofori, G. 2015. Nature of the construction industry, its needs and its development: A review of four decades of research. Journal of Construction in Developing Countries, 20(2), pp. 115-135.

[6] Kibert, C.J. 2016. Sustainable construction: Green building design and delivery, $4^{\text {th }}$ ed. New Jersey, The United States. John Wiley and Sons.

[7] Darko, A. \& Chan, A.P.C. 2016. Critical analysis of green building research trend in construction journals. Habitat International, 57, pp. 53-63.

[8] Du Plessis, C. 2005. Action for sustainability: Preparing an African plan for sustainable building and construction. Building Research and Information, 33(5), pp. 405-415.

[9] Whittemore, R. \& Knafl, K. 2005. The integrative review: Updated methodology. Journal of Advanced Nursing, 52(5), pp. 546-553.

[10] Stemler, S. 2001. An overview of content analysis. Practical Assessment, Research and Evaluation, 7(17), pp. 1-6.

[11] Hsieh, H.F. \& Shannon, S.E. 2005. Three approaches to qualitative content analysis. Qualitative Health Research, 15(9), pp. 1277-1288.

[12] Elo, S. \& Kyngäs, H. 2008. The qualitative content analysis process. Journal of Advanced Nursing, 62(1), pp. 107115.

[13] Bengtsson, M. 2016. How to plan and perform a qualitative study using content analysis. NursingPlus Open, 2, pp. 8-14.

[14] Chang, R.D., Zuo, J., Soebarto, V., Zhao, Z.Y., Zillante, G. \& Gan, X.L. 2016. Sustainability transition of the Chinese construction industry: Practices and Behaviors of the Leading Construction Firms. Journal of Management in Engineering, 32(4), 05016009.

[15] Pitt, M., Tucker, M., Riley, M. \& Longden, J. 2009. Towards sustainable construction: Promotion and best practices. Construction Innovation, 9(2), pp. 201- 224.

[16] Ismail, Z., Idris, N.H., \& Nasir, N.M. 2012. Sustainable initiative and impediments towards promoting sustainable construction in Malaysia. In IEEE Colloquium on Humanities, Science and Engineering Research (CHUSER), pp. 32 37.

[17] Serpell, A., Kort, J. \& Vera, S. 2013. Awareness, actions, drivers and barriers of sustainable construction in Chile. Technological and Economic Development of Economy, 19(2), pp. 272-288.

[18] Shi, Q., Zuo, J., Huang, R., Huang, J. \& Pullen, S. 2013. Identifying the critical factors for green construction An empirical study in China. Habitat International, 40, pp. 1-8.

[19] Wilson, I.E. \& Rezgui, Y. 2013. Barriers to construction industry stakeholders' engagement with sustainability: Toward a shared knowledge experience. Technological and Economic Development of Economy, 19(2), pp. 289309.

[20] AlSanad, S. 2015. Awareness, drivers, actions, and barriers of sustainable construction in Kuwait. Procedia Engineering, 118, pp. 969-983.

[21] Ametepey, O., Aigbavboa, C. \& Ansah, K. 2015. Barriers to successful implementation of sustainable construction in the Ghanaian construction industry. Procedia Manufacturing, 3, pp. 1682-1689.

[22] Gan, X., Zuo, J., Ye, K., Skitmore, M. \& Xiong, B. 2015. Why sustainable construction? Why not? An owner's perspective. Habitat International, 47, pp. 61-68.

[23] Khalfan, M., Noor, M.A., Maqsood, T., Alshanbri, N. \& Sagoo, A. 2015. Perceptions towards sustainable construction amongst construction contractors in State of Victoria, Australia. Journal of Economics, Business and Management, 3(10), pp. 940-947.

[24] Saleh, M.S. \& Alalouch, C. 2015. Towards sustainable construction in Oman: Challenges and opportunities. Procedia Engineering, 118, pp. 177-184.

[25] Aigbavboa, C., Ohiomah, I. \& Zwane, T. 2017. Sustainable construction practices: ‘A lazy view’ of construction professionals in the South Africa construction industry, Energy Procedia, 105, pp. 3003-3010.

[26] Chan, A.P.C., Darko, A., Ameyaw, E.E. \& Owusu-Manu, D.G. 2017. Barriers affecting the adoption of green building technologies. Journal of Management in Engineering, 33(3), pp. 1-12.

[27] Darko, A., Chan, A.P.C., Ameyaw, E.E., He, B.J. \& Olanipekun, A.O. 2017. Examining issues influencing green building technologies adoption: The United States green building experts' perspectives. Energy and Buildings, 144, pp. 320-332.

[28] Hwang, B., Shan, M. \& Supa'at, N.N.B. 2017. Green commercial building projects in Singapore: Critical risk factors and mitigation measures. Sustainable Cities and Society, 30, pp. 237-247.

[29] Darko, A., Chan, A.P.C., Yang, Y., Shan, M., He, B.J. \& Gou, Z. 2018. Influences of barriers, drivers, and promotion strategies on green building technologies adoption in developing countries: The Ghanaian case. Journal of Cleaner Production, 200, pp. 687-703.

[30] Chan, A.P.C., Darko, A., Olanipekun, A.O. \& Ameyaw, E.E. 2018. Critical barriers to green building technologies adoption in developing countries: The case of Ghana. Journal of Cleaner Production, 172, pp. 1067-1079.

[31] Munyasya, B.M. \& Chileshe, N. 2018. Towards sustainable infrastructure development: Drivers, barriers, strategies, and coping mechanisms. Sustainability, 10, 4341.

[32] Klufallah, M., Ibrahim, I.S. \& Moayedi, F. 2019. Sustainable practices barriers towards green projects in Malaysia. IOP Conference Series: Earth and Environmental Science, 220, 012053.

[33] Pham, H., Kim, S.Y. \& Luu, T.V. 2019. Managerial perceptions on barriers to sustainable construction in developing countries: Vietnam case. Environment, Development and Sustainability, 22, pp. 2979-3003. 
[34] Ahn, Y.H., Pearce, A.R., Wang, Y. \& Wang, G. 2013. Drivers and barriers of sustainable design and construction: The perception of green building experience. International Journal of Sustainable Building Technology and Urban Development, 4(1), pp. 35-45.

[35] Opoku, A. \& Ahmed, V. 2014. Embracing sustainability practices in UK construction organizations: Challenges facing intra-organizational leadership. Built Environment Project and Asset Management, 4(1), pp. 90-107.

[36] Abidin, N.Z. \& Powmya, A. 2014. Perceptions on motivating factors and future prospects of green construction in Oman. Journal of Sustainable Development, 7(5), pp. 231-239.

[37] Djokoto, S.D., Dadzie, J. \& Ohemeng-Ababio, E. 2014. Barriers to sustainable construction in the Ghanaian construction industry: Consultants perspectives. Journal of Sustainable Development, 7(1), pp. 134-143.

[38] Mousa, A. 2015. A business approach for transformation to sustainable construction: An implementation on a developing country. Resources, Conservation and Recycling, 101, pp. 9-19.

[39] Lim, B.T.H., Liu, A.Z.J. \& Oo, B.L. 2019. Awareness and practices of sustainable construction in Australia: Consultant quantity surveyors' perception. In D.C.J Chieh (Ed.), AIP Conference Proceedings, $2124,020060$. Penang, Malaysia: AIP Publishing.

[40] Marker, A.W., Mason, S.G. \& Morrow, P. 2014. Change factors influencing the diffusion and adoption of green building practices. Performance Improvement Quarterly, 26(4), pp. 5-24.

[41] Marchman, M. \& Clarke, S.N. 2011. Overcoming the barriers to sustainable construction and design through a cross-reference of West Coast practices. In T. Sulbaran (Ed.), 47th ASC Annual International Conference Proceedings. Nebraska, The United States.

[42] Häkkinen, T. \& Belloni, K. 2011. Barriers and drivers for sustainable building. Building Research and Information, 39(3), pp. 239-255.

[43] Samari, M., Godrati, N., Esmaeilifar, R., Olfat, P. \& Shafiei, M.W.M. 2013. The investigation of the barriers in developing green building in Malaysia. Modern Applied Science, 7(2), pp. 1-10.

[44] Brennan, M.C. \& Cotgrave, A.J. 2014. Sustainable development: A qualitative inquiry into the current state of the UK construction industry. Structural Survey, 32(4), pp. 315-330.

[45] Shari, Z. \& Soebarto, V.I. 2012. Delivering sustainable building strategies in Malaysia: Stakeholders' barriers and aspirations. Alam Cipta, 5(2), pp. 3-12.

[46] Oke, A., Aghimien, D., Aigbavboa, C. \& Musenga, C. 2019. Drivers of sustainable construction practices in the Zambian construction industry. Energy Procedia, 158, pp. 3246-3252.

[47] Yin, B.C.L., Laing, R., Leon, M. \& Mabon, L. 2018. An evaluation of sustainable construction perceptions and practices in Singapore. Sustainable Cities and Society, 39, pp. 613-620.

[48] Chan, A.P.C., Darko, A. \& Ameyaw, E.E. 2017. Strategies for promoting green building technologies adoption in the construction industry - An international study. Sustainability, 9, 969.

[49] Windapo, A.O. 2014. Examination of green building drivers in the South African construction industry: Economics versus ecology. Sustainability, 6, pp. 6088-6106.

[50] Jiang, W. \& Wong, J.K.W. 2016. Key activity areas of corporate social responsibility (CSR) in the construction industry: A study of China. Journal of Cleaner Production, 113, pp. 850-860.

[51] Zhang, Q., Oo, B.L. \& Lim, B.T.H. 2019. Drivers, motivations, and barriers to the implementation of corporate social responsibility practices by construction enterprises: A review. Journal of Cleaner Production, 210, pp. 563584.

[52] Darko, A., Zhang, C. \& Chan, A.P.C. 2017. Drivers for green building: A review of empirical studies. Habitat International, 60, pp. 34-49. 